DOI: 10.20472/IAC.2019.045.016

\author{
ABE HARRAF \\ University of Northern Colorado, United States

\section{THE IMPACT OF THE BREXIT VOTE ON EU MULTINATIONAL COMPANIES}

\begin{abstract}
:
The Brexit vote and its final outcome on EU multinational companies that are operating in United Kingdom is predicted to have adverse economic and financial outlook for the country. Such consequences could be broken down into three profound impacts: financial, economic and legal, and labor mobility. Financial implications are expected to be harmful in the form of higher business and administrative costs, decrease in foreign direct investment (FDI) in the United Kingdom, and fallout for some selected industries. Economic and legal consequences of the vote are equally inevitable to take a toll on the country and its businesses that their business operation are closely tied to other EU countries. The Brexit would potentially cause an increase in the trading costs for EU multinational companies, looking to engages in international trade while operating in the UK. Moreover, the economic effects of the Brexit vote could potentially result in inflation and increase in the costs of imported goods for United Kingdom residents. Further negative economic implications such as volatility of the English Pound and of the economy in the short-term might result. In addition, leaving EU will likely result in reduced labor mobility and immigration, devastating Britain businesses due to an increased labor cost that are further challenged with the aging population that is prevalent in the most of the western Europe economies. Such difficulties will likely result in the major multinational corporations to opt to forego their operations in the United Kingdom and move their headquarters and business enterprises to another European country. Through the exploration of these potentially harmful impacts on the Great Britain economy, the paper attempts to support the hypothesis that Brexit initiative would have many unintended consequences that could devastate the Great Britain economy for some time.
\end{abstract}

\title{
Keywords:
}

Brexit, European Union, International Trade 